\title{
Efficacy of Manually Prepared Single Super Phosphate Fertilizer on Rain-Fed Wheat Crop under Sub-Humid Climate
}

\section{Matiullah Khan*, Shameemul Sibtain Shah, Atiqullah Khan, Muhammad Sarwar and Shoaib Ahmed}

Land Resources Research Institute, National Agricultural Research Centre, Park Road, Islamabad, 45500, Pakistan.

Abstract | Field experiments were conducted during 2015-16 at National Agricultural Research Center Islamabad to evaluate the availability of $\mathrm{P}$ from different particle size of Hazara rock phosphate (HRP) by manual preparation of Single Super Phosphate (SSP) through the procedure already established by the author and testing its efficacy in comparison to DAP on rainfed wheat. Almost 50 bags of SSP were prepared using formula "100 kg of indigenous HRP with total $\mathrm{P}_{2} \mathrm{O}_{5}$ content of $\mathrm{X}$ and mesh size 160 when treated with 60 liters (50\% diluted) $\mathrm{H}_{2} \mathrm{SO}_{4}$ (volume/volume), followed by proper curing, yields SSP of almost $\mathrm{X} / 2 \%$ extractable $\mathrm{P}_{2} \mathrm{O}_{5}$ ” The $\mathrm{P}$ was applied @ 57.5 $\mathrm{kg} \mathrm{P}_{2} \mathrm{O}_{5}$ ha $^{-1}$ both from prepared SSP and DAP to wheat crop on equal $\mathrm{P}_{2} \mathrm{O}_{5}$ basis. Also, Phosphate Solubilizing Bacteria (PSB) were tested in this experiment for yield and $\mathrm{P}$ uptake of the crop. The results showed that smaller the mesh size of HRP 200 mesh gave maximum available $\mathrm{P}_{2} \mathrm{O}_{5}$ 14.27\% followed by 160 mesh with $14.21 \%$, from the stock grade HRP containing $28 \%$ total $\mathrm{P}_{2} \mathrm{O}_{5}$. The free acid contents were equal and lower (5\%) in the prepared SSP for mesh size 160 and 200, against $6.3 \%$ when mesh size was 120 . The SSP application as $\mathrm{P}$ source increased grain yield and total dry matter yield 2.5\% and 4.7\% over DAP, respectively. Similarly, SSP application enhanced P uptake of crop by $5.6 \%$ over DAP, however, no increase in postharvest soil $\mathrm{P}$ concentration was recorded. Seed inoculation with PSB significantly increased grain and dry matter yield. It can be concluded from the study that good quality of SSP can be manually prepared from HRP which may increase the yield comparable to DAP.

Received | February 28, 2019; Accepted | June 24, 2019; Published | August 12, 2019

*Correspondence | Dr. Matiullah Khan, Land Resources Research Institute, National Agricultural Research Centre, Park Road, Islamabad, 45500, Pakistan; Email: mukhan65pk@yahoo.co.uk

Citation | Khan, M., S.S. Shah, A. Khan, M. Sarwar and S. Ahmed. 2019. Efficacy of manually prepared single super phosphate fertilizer on rain-fed wheat crop under sub-humid climate. Pakistan Journal of Agricultural Research, 32(3): 527-534.

DOI | http://dx.doi.org/10.17582/journal.pjar/2019/32.3.527.534

Keywords | Single superphosphate, Phosphorus availability, P uptake, Grain yield, Free acid contents

\section{Introduction}

$\mathrm{P}$ hosphorus $(\mathrm{P})$ is second macro-nutrient considered essential for plant growth. Physiological functions such as cell division and development, photosynthesis, the breakdown of sugar energy and transfer within the plant depends on P (Sharma, 2005). The application of $\mathrm{P}$ to crops increases root development, water-use efficiency and the plant's resistance to moisture stress. Phosphorus also contributes to straw strengthening in cereal crops as well as crop quality, especially in forages and vegetables.

Most of the soils in Pakistan are alkaline calcareous, a condition proven to $\mathrm{P}$ fixation, making $\mathrm{P}$ deficiency a widespread phenomenon (Sharif et al., 2000; Rashid, 
2005). The widespread alkalinity and calcareousness in soils of Pakistan has resulted in 93\% $\mathrm{P}$ deficiency (Nisar and Rashid, 2003), less than $10 \mathrm{mg} \mathrm{kg}$ extractable P (Memon et al., 1991). The added P fertilizer when dissolve into soil solution, a large amount of $\mathrm{P}$ from the soil solution is firmly adsorb on soil cation. Thus, the adsorbed $\mathrm{P}$ becomes unavailable to the plants for a long period (Huang, 1998). The demand for $\mathrm{P}$ fertilizers therefore increases with increase in $\mathrm{pH}$ especially beyond 7.5 , due to increase in $\mathrm{P}$ fixation. Plant takes up only small amount of $\mathrm{P}$; rest of the $\mathrm{P}$ is either permanently or temporarily fixed on to soil. The chelated $\mathrm{P}$ or residual $\mathrm{P}$, becomes available but at slow rates (Sharif et al., 2000). Soil $\mathrm{P}$ availability is influenced by many factors such as soil reactions, amount and form of $\mathrm{P}$ as well as soil type. More $\mathrm{P}$ fertilization was suggested in high claycalcareous soils (Tisdale et al., 2002).

Huge amount of $\mathrm{P}$ fertilizers application is therefore, indispensable for better crop production. According to statistics, out of 881 thousand nutrient tones (TNT) demand every year, 432 TNT P fertilizers are imported to cope up with $\mathrm{P}$ fertilizer needs (Anonymous, 2014). Out of the 22.75 million hectares (Mha) of cropped area of Pakistan, 19.08 Mha are irrigated where 881 TNT P fertilizers were consumed during the year 2013-14, showing the application of $39 \mathrm{Kg} \mathrm{ha}{ }^{-1}$ which is almost equivalent to $1 / 3^{\text {rd }}$ of the recommended dose (Anonymous, 2014). The basic reason behind the under-dose application of $\mathrm{P}$ fertilizers might be the higher prices (Aujla et al., 2010). The price of widely used $P$ fertilizer DAP is almost triple as compared to nitrogen (Nisar, 1996), The recommended dose of $\mathrm{P}$ fertilizers applied to any food crop or cash crop costs almost equivalent to the cost of all other inputs required. Besides the irrigated areas, the demand for $\mathrm{P}$ fertilizers is also increasing in humid to sub-humid rain-fed areas, especially where double cropping per year is in practice.

Pakistan is bestowed with rock-phosphate deposits in the Hazara area of Khyber Pakhtunkhwa province, the raw material used for preparation of all type of phosphate fertilizers. (Figure 1). Primarily, these RP reserves contain $\mathrm{Ca}_{3}\left(\mathrm{PO}_{4}\right)_{2}$, a water insoluble and plant unavailable $\mathrm{PO}_{4}$ molecule (Brady, 1990; Das, 2005). The HRP reserves are found in the form of schist, shale or limestone, dolomites or phosphorite and ortho-quartizite at various villages of district Abbottabad, Pakistan (Javed et al., 2008). Total reserve stands to be 35.7 million tones (unpublished data), which could sustain the country's $P$ requirement for nearly 30 years. However, visual observation and discussions between the author and the stake-holders confirm that the total reserves might be many more than ever-reported. Keeping in view the worth of HRP reserves, the study was conducted to investigate the extant of $\mathrm{P}$ solubilized from HRP through acidulation method (Khan et al., 2012) at farm level in the form of SSP, devise simple on farm formulation and check effects on wheat crop in calcareous soils under rain-fed condition. The way forward of the study is to devise small-scale SSP unit at farm level so as to farmers get $\mathrm{P}$ fertilizers at cheaper rates.

\section{Materials and Methods}

\section{Preparation of SSP from HRP at farm level}

Field experiments were conducted during the year 2015-16 at National Agricultural Research Center, Islamabad for on-farm manual preparation Single Super Phosphate (SSP) from Hazara rock phosphate (HRP) and determination of its available $\mathrm{P}$ content. Fifty bags of SSP was manually prepared using formula already tested by the author (Fertilizer Manual, 1979; Khan et al., 2012). The HRP having $28 \% \mathrm{P}_{2} \mathrm{O}_{5}$ with mesh sizes of $120-200$ was used in the experiment. The commercial grade sulfuric acid (98\%) was purchased from local acid-industry. The sulfuric acid was diluted to 50\% (volume/volume) by adding tap water. The dilutions were done slowly and gradually by adding acid into water in strongplastic used-drums. The highest temperature recorded during dilution was $135^{\circ} \mathrm{C}$. Continuous cooling of the drum's outer side was carried out with application of tap water so as to prevent any damage to plastic due to high temperature. The diluted acid was kept overnight in the same drum to cool down to almost room temperature. A stainless-steel pan $(2.5 \mathrm{~m} \times$ $2.5 \mathrm{~m}$ ) with raised edges was used to conduct reaction between acid and HRP for preparation of SSP. All the three-mesh size HRP's, i.e. 120,160 and 200 were treated separately to test the effect of mesh size on $\mathrm{P}$ availability from these HRP's. Measured $100 \mathrm{~kg}$ HRP was spread in the pan and 60 liters of the diluted acid was applied slowly and gradually, followed by thorough mixing with spades. After thorough mixing, the mixture was shifted to a shady place, dumped and covered with polythene sheet. Proper precautionary measures for safety of the laborers were adopted while diluting sulfuric acid and conducting reactions. 


\section{SPATIAL DISTRIBUTION OF PHOSPHORUS PENTA OXIDE IN ROCK PHOSPHATE RESERVES} (ABBOTTABAD)

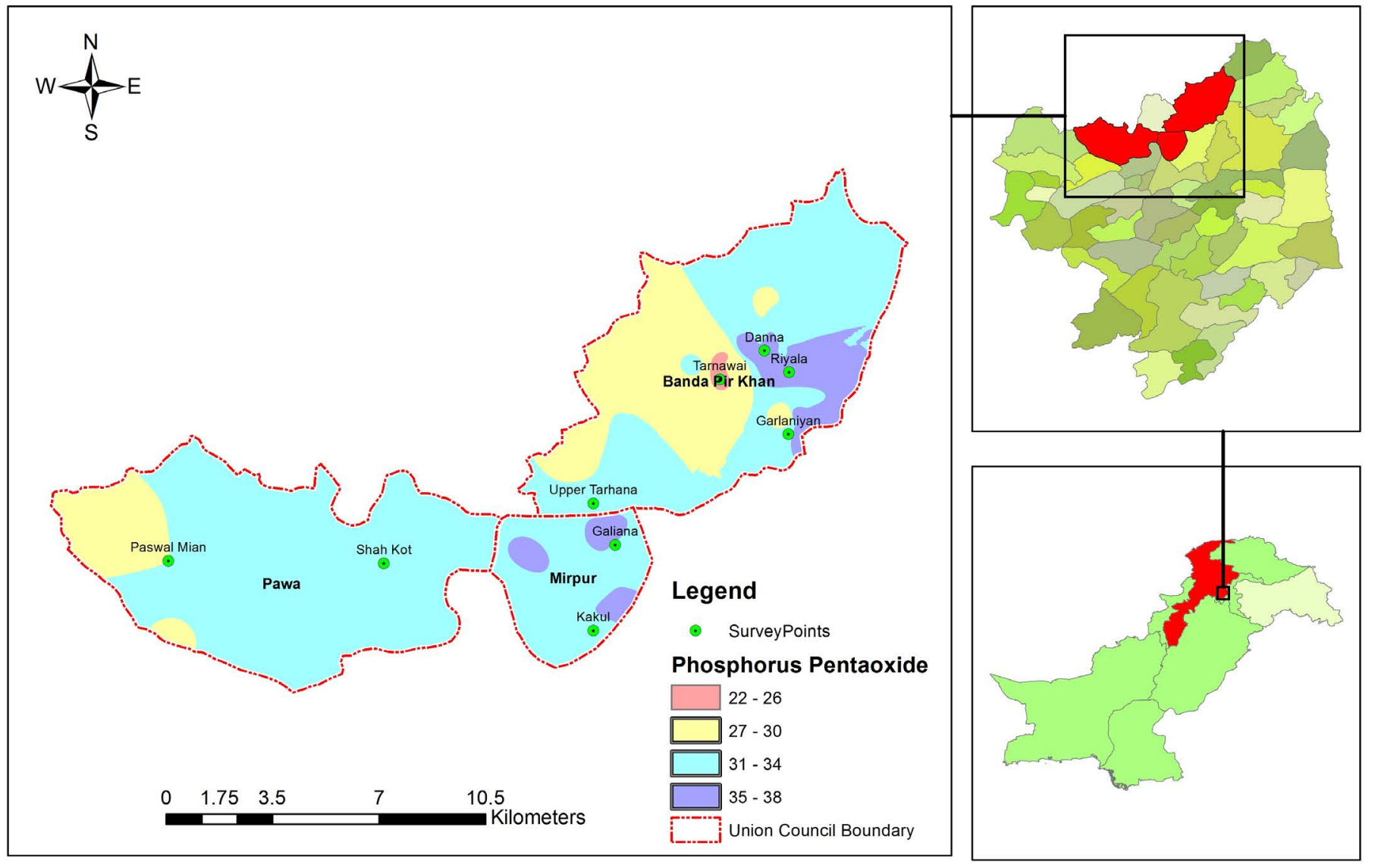

Figure 1: Geographical location of rock phosphater reserves in Hazara, KPK.

After complete mixing, the material was kept for curing in the same place. After curing for 40 days, the material was spread in the sunlight for drying. The crumbs were broken, sieved through $6 \mathrm{~mm}$ screen followed by $2 \mathrm{~mm}$ for obtaining SSP-grain of desired size. The rest of the material above $6 \mathrm{~mm}$ was crushed again and sieved. The material below $2 \mathrm{~mm}$ was bagged separately as powdered SSP. Random samples were collected from the stock-material and analyzed for available $\mathrm{P}$ and free acid content before its application to crop.

\section{Field experiment}

Response of SSP to wheat yield: The so prepared SSP was applied to wheat crop with comparison to DAP at National Agricultural Research Center (NARC), Islamabad at $33.7167^{\circ} \mathrm{N}$ and $73.0667^{\circ} \mathrm{E}$ during the year 2015-16 (November to May). Phosphate Solubilizing Bacteria (PSB) (a bio-fertilizer prepared by NARC) alone and in combination with both the $\mathrm{P}$ fertilizers was also applied to record its efficacy. The experiment was designed according to the two factorial Randomized Complete block designs with three replications. The PSB (with and without) was kept in main plot as factor 1 , and factor 2 as $\mathrm{P}$ from $\mathrm{DAP}$ at the rate of (one Bag per acre farmers 'practice) $57.5 \mathrm{Kg} \mathrm{P}_{2} \mathrm{O}_{5}$ ha $^{-1}, \mathrm{P}$ from self-SSP at the rate of 57.5 $\mathrm{Kg} \mathrm{P}_{2} \mathrm{O}_{5}$ ha $^{-1}$, and $\mathrm{P}$ from SSP at the rate of $57.5 \mathrm{Kg}$ $\mathrm{P}_{2} \mathrm{O}_{5}$ ha $^{-1}+$ split $\mathrm{N}$ equivalent to DAP's $\mathrm{N}$ with rain at booting stage. Before onset of experiment, soil sample was randomly collected from various location of selected field for determination of soil physical and chemical properties (Table 1). The experiment was planted on two hectares rainfed-land of NARC specified for seed multiplication. The plot size for each treatment was $10 \mathrm{~m} \times 30 \mathrm{~m}$ having one-meter separation path. Fertilizer was manually broadcasted in each treatment separately, followed by Rotavator operation for better mix up in the soil. Sowing of wheat seed variety Pakistan-2013 was done with the tractor-mounted wheat-drill on $29^{\text {th }}$ November 2015. Prior to sowing, the wheat seed was inoculated with PSM. Harvesting of each treatment was separately done with the experiment-harvesting machine. Grain yield, yield components, dry biomass and $\mathrm{P}$ uptake of crop data were recoded for concluding results of the 
experiment. The meteorological data including mean maximum and minimum temperature, and mean monthly rainfall, was recorded at meteorological station, NARC, Islamabad during the study period (Figure 2 and 3).

Table 1: Physio-chemical characteristics of the soil.

$\begin{array}{lll}\text { Property } & \text { Unit } & \text { Values } \\ \text { Textural class } & - & \text { Sandy loam } \\ \mathrm{pH} & - & 7.73 \\ \mathrm{EC} & \left(\mathrm{ds} \mathrm{m}^{-1}\right) & 0.51 \\ \text { Organic matter } & \% & 0.77 \\ \mathrm{~N} & \mathrm{mg} \mathrm{kg}^{-1} & 4.04 \\ \text { Extractable P } & \mathrm{mg} \mathrm{kg}^{-1} & 5.22 \\ \mathrm{~K} & \mathrm{mg} \mathrm{kg}^{-1} & 76.0\end{array}$

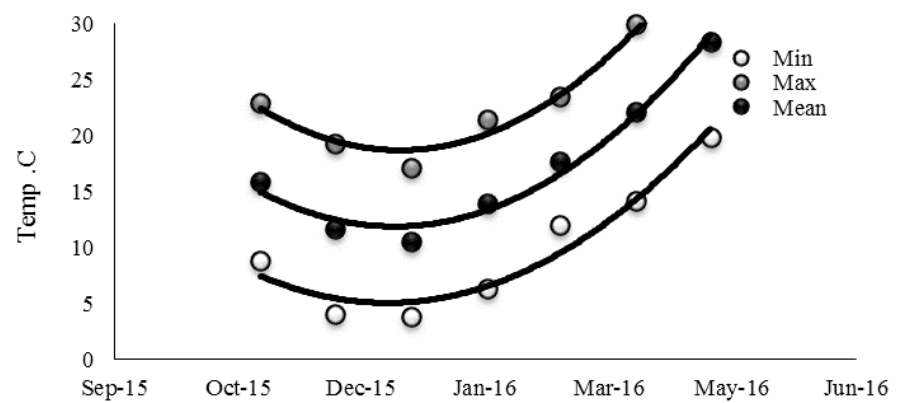

Figure 2: Mean maximum and minimum temperature.

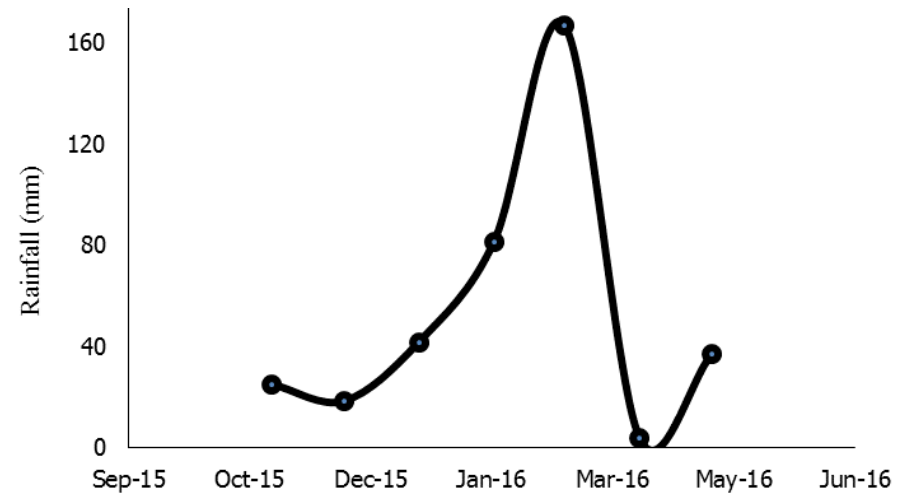

Figure 3: Mean maximum and minimum temperature.

\section{Data collection and samples analysis}

At maturity, data on plant height, the number of grains per spike, grain yield and the total drymatter yield were recorded according to the standard procedures. Post-harvest total dry-matter samples of the crop were collected and ground for determining the plant nutrient uptake. Post-harvest soil samples were collected and analyzed for physical and chemical properties such as texture class (Koehler, 1984), $\mathrm{pH}$, EC (McClean, 1982), total organic carbon (TOC) (Tandon et al., 2005), P and K (AB-DTPA extractable) Soultanpour et al. (1979). Post-harvest N and $\mathrm{P}$ concentration in plant tissues were determined following Kjeldahl method (Ryan et al., 2001), and the Wet-Digestion Method (Jackson, 1973), respectively. The total $\mathrm{P}$ concentration in soil was determined by the procedure of Olsen and Sommers (1982). The soil texture class was determined by the Dispersion Method as prescribed for the determination of $\mathrm{NO}_{3}-\mathrm{N}$, extractable $\mathrm{P}$ and $\mathrm{K}$ in the soil, a multi-element determination extractant of Ammonium Bicarbonate -Di-ethylene Tri-amine Penta Acetic Acid (ABDTPA) procedure (Ryan et al., 2001) was followed. Organic matter in the soil was determined by the Titration Method (Nelson and Sommers, 1982). The moisture content in the soil was determined by the Gravimetric Method as prescribed by Gardner (1986).

\section{Statistical analysis and map drawing}

Statistical tests were performed using one-way analysis of variance was run on plant parameters (grain and straw yield), and two-way ANOVA to test the interaction between biozote, SSP. Fisher's least significant difference (LSD) tests were used to distinguish among treatment means (Gomez and Gomez, 1982). Location of experiment site was shown by a map drawing on ArcMap 10.1(C 19952012 Esri, USA).

\section{Results and Discussion}

\section{Preparation of SSP from RP at farm level}

The chemical analysis showed that general-stock grade HRP reserve of Guldania, Hazara had average contents of $28 \% \mathrm{P}_{2} \mathrm{O}_{5}$. After reaction, the available $\mathrm{P}_{2} \mathrm{O}_{5}$ in prepared SSP ranged from $13.45 \%$ to $14.27 \%$ among the treatments comprising of different mesh sizes. The highest $\mathrm{P}$ availability (14.27\%) was recorded in the treatment where mesh size was 200, followed by 160 mesh size, giving $14.21 \% \mathrm{P}_{2} \mathrm{O}_{5}$ with non-statistical difference. It implies that as size gets smaller, the greater is the availability of $\mathrm{P}$ from HRP by reaction with $\mathrm{H}_{2} \mathrm{SO}_{4}$. Such behavior could be ascribed to greater surface area with smaller particle size, resulting in having more contact with acid. Goenadi et al. (2000) reported similar conclusions of research that soil $\mathrm{pH}$, soil phosphorus fixing capacity, and size of rock phosphate granules play a major role in phosphorus availability in soil. Our findings show that particle size more $>160$ mesh gave more availability of $\mathrm{P}_{2} \mathrm{O}_{5}$ but was very meager and seemed uneconomical (Table 2), because smaller mesh size involves more labour. 
Table 2: Availability of $P$ and free acid content as affected by particle size of $R P$.

$\begin{array}{lll}\begin{array}{l}\text { RP particle size } \\ \text { (Mesh size) }\end{array} & \mathbf{P}_{2} \mathbf{O}_{5} \text { content (\%) } & \text { Free acid content (\%) } \\ \mathbf{1 2 0} & 13.45 \mathrm{~b} & 6.3 \\ \mathbf{1 6 0} & 14.21 \mathrm{a} & 5.2 \\ \mathbf{2 0 0} & 14.27 \mathrm{a} & 5.0\end{array}$

Free acid content (FAC) indicates extent of reaction occur between the $\mathrm{HRP}$ and $\mathrm{H}_{2} \mathrm{SO}_{4}$. Only up to $5 \%$ free acid is allowable in a final product SSP (Fertilizer Manual, 1979) as higher FAC render it more hygroscopic and crumby in appearance. Our experiments on FAC with different mesh size of HRP showed that HRP mesh size 160 and 200 yielded optimum FAC while, 120 mesh gave higher FAC (6.33\%) (Table 2). It implies that the HRP with mesh size 160 and 200 are best for manufacture of SSP at small scale.

\section{Grain yield}

The data averaged across the sub-plot for comparison of effect ofDAP and self-prepared SSP and application of split N with SSP (irrespective of biozote) showed significant variation in grain yield of wheat sown under rain-fed conditions (Table 3 ). The results showed that same amount of $\mathrm{P}$ either applied from DAP or selfprepared SSP gave significantly $(P \leq 0.05)$ at par grain yield, however, generally, the SSP gave $2.5 \%$ increased grain yield over DAP. This might be due to the reason that powder-type SSP released $\mathrm{P}$ instantly under rainfed/low soil-moisture condition, while the granular DAP would have slow $\mathrm{P}$ release due deficiency of soil-moisture required for its dissolution. The acidic nature of SSP fertilizer might had shown superior effect over DAP. Besides the sulfur content of SSP which an essential macronutrient for plants is, the lower $\mathrm{pH}$ of SSP as compared to DAP and gypsum content in SSP would have attributed towards this yield advantage. The lowers soil $\mathrm{pH}$ in rhizosphere due to SSP application may enhance the uptake of other micronutrients could be a justification for the yield advantage of SSP over DAP. These results are in accordance with Mushtaq et al. (2015) who concluded that application of SSP showed better results on grain yield of wheat as compared to nitrophos (NP), DAP, mono-ammonium phosphate (MAP) and triple superphosphate (TSP) on P deficient soil. Khan et al. (2010) concluded that $\mathrm{P}$ application at the rate of 80 $\mathrm{kg} \mathrm{P} \mathrm{ha} a^{-1}$ as SSP showed better results as compared to TSP, NP and DAP on P deficient soil of Balkasr area of tehsil Chakwal. Similar results have been reported by Reddy and Singh (2003) and Alam et al. (2002).

Table 3: F-Values of ANOVA for the effects of SSP, DAP and Biozote on wheat crop.

\begin{tabular}{llllll} 
SOV & DF Soil P & \multicolumn{2}{c}{$\begin{array}{l}\text { P-uptake Grain Yield TDM } \\
\left(\mathbf{m g ~ k g}^{-1}\right)\end{array}$} \\
$\begin{array}{llllll}\left(\mathbf{k g ~ h a}^{-1}\right) & \text { Yield }\left(\mathbf{k g ~ h a}^{-1}\right)\end{array}$ \\
Main plot & 1 & $65.13^{* *}$ & $114.17^{* *}$ & $236.72^{* *}$ & $144.70^{* *}$ \\
Sub-plot & 2 & $85.98^{* *}$ & $968.87^{* *}$ & $61.01^{* *}$ & $6.14^{*}$ \\
$\begin{array}{l}\text { Main-plot } \times S- \\
\text { ub-plot }\end{array}$ & 2 & $3.66^{*}$ & $0.99 \mathrm{NS}$ & 0.35 NS & $0.15 \mathrm{NS}$ \\
& & & & &
\end{tabular}

SOV: Source of variations; DF: Degree of Freedom; Soil P: post-harvest soil Phosphorus; TDM: Total Dry-Matter Yield; Main plot: Biozote effect; Sub-plot: P sources effect; ": Significant at $P \leq 0.05$; *: Significant at $P \leq 0.01 ; \mathrm{NS}$ : non-significant.

The split application of $\mathrm{N}$ ( $\mathrm{N}$ dose equal to the $\mathrm{N}$ in applied DAP was applied with first rain-showers received in last week of January 2016) with selfprepared SSP, however gave significantly the highest grain yield over DAP and SSP. This treatment gave yield advantage of $16.9 \%$ and $14 \%$ over DAP and self-prepared SSP which received all the $\mathrm{N}$ at time of sowing, respectively. Split application of $\mathrm{N}$ can decrease the $\mathrm{N}$ losses very specially in rainfed conditions. This technology can only be adopted by the small landholders rainfed wheat grower because, the fertilizers spreader used for large scale fertilizer application could not be used in standing crop. The data averaged across the sub-plots for determining the effect of Biozote inoculation showed that the treatment "with Biozote" gave significantly $(p \leq 0.05)$ higher grain yield of $3728 \mathrm{~kg} \mathrm{ha}{ }^{-1}$ over "without Biozote" producing $3421 \mathrm{~kg} \mathrm{ha}^{-1}$ with yield advantage of $8.56 \%$. Generally, the Biozote gave more aggressive effect in the treatments giving lesser yield, might be proving that lesser the nutrient availability/more the yield gap, more will be the microbe efficiency. Aslam et al. (2011) reported that the selected PSB proved very effective in solubilizing $\mathrm{P}$ and in lowering $\mathrm{pH}$ in liquid culture. The mechanism of solubilizing $\mathrm{P}$ through microorganism is also related to acid production (Kumari et al., 2008; Kepert et al., 1979). Phosphate solubilizing microorganisms create protons or acids in the rhizosphere and as a result more $\mathrm{P}$ is solubilized and made available to the plant (Molla and Chowdhary, 1984).

\section{Dry matter yield}

The data averaged across the sub-plots for determining effect of DAP, self-prepared SSP and SSP with split 
$\mathrm{N}$ showed significant variation on dry matter yield of rainfed wheat. Although the dry matter yield produced by the self-prepared SSP was statistically at par with the DAP produced yield but, generally, the self-prepared SSP produced increased yield over DAP. The significantly highest Dry matter yield of $11.1 \mathrm{t}$ $\mathrm{ha}^{-1}$ was produced by the treatment receiving selfprepared SSP along with Split application of N from Urea. Biozote inoculation also significantly enhanced the dry matter yield over non-inoculated treatment, irrespective of the source of $\mathrm{P}$ fertilizers. The dry matter yield produced through Biozote inoculation was higher than the non-inoculation (Table 4).

Table 4: Effects of SSP, DAP and biozote on grain and dry matter yield of wheat.

\section{Grain yield ( $\left.\mathrm{kg} \mathrm{ha}^{-1}\right)$}

$\begin{array}{lllll}\text { Biozote } & \text { DAP } & \text { Self-SSP } & \text { Self-SSP+Split N } & \text { Mean } \\ \text { With } & 3529 \mathrm{c} & 3604 \mathrm{c} & 4052 \mathrm{a} & 3728 \mathrm{~A} \\ \text { Without } & 3187 \mathrm{~d} & 3280 \mathrm{~d} & 3798 \mathrm{~b} & 3421 \mathrm{~B} \\ \text { Mean } & 3358 \mathrm{~B} & 3442 \mathrm{~B} & 3925 \mathrm{~A} & \\ \text { Dry matter yield }\left(\mathrm{t} \mathrm{ha} \mathrm{C}^{-1}\right) & & \\ \text { Biozote } & \text { DAP } & \text { Self-SSP } & \text { Self-SSP+Split N } & \text { Mean } \\ \text { With } & 10.75 \mathrm{ab} & 11.00 \mathrm{ab} & 11.45 \mathrm{a} & 11.06 \mathrm{~A} \\ \text { Without } & 9.90 \mathrm{~d} & 10.05 \mathrm{~cd} & 10.75 \mathrm{bc} & 10.23 \mathrm{~B} \\ \text { Mean } & 10.32 \mathrm{~B} & 10.52 \mathrm{~B} & 11.10 \mathrm{~A} & ------\end{array}$

SSP: Single superphosphate; DAP: Diammonium phosphate; Means followed by different letter(s) are statistically different $(p<0.05)$.

\section{P-uptake of crop}

The results showed significant variations among different treatments (DAP, self SSP and SSP + Split $\mathrm{N})$ for $\mathrm{P}$ uptake of wheat. The highest $\mathrm{P}$-uptake $\left(18.05 \mathrm{~kg} \mathrm{ha}^{-1}\right)$ was recorded in the treatment where self-prepared SSP + Spilt N was applied, followed by $17.34 \mathrm{~kg} \mathrm{ha}^{-1}$ with self-prepared SSP only, while the lowest in treatment where only DAP was applied. Our findings show the effectiveness of $\mathrm{P}$ in term of plant $\mathrm{P}$ uptake where self-prepared SSP was applied against DAP. Seed inoculation with biozote also resulted in significant effect on P-uptake of wheat. It was found that with biozote application gave P-uptake of 15.62 $\mathrm{kg} \mathrm{ha}{ }^{-1}$ against $14.97 \mathrm{~kg} \mathrm{ha}^{-1}$ where biozote was not applied (Table 5).

\section{Post-harvest soil P content}

The result showed significant variations among the treatments for post-harvest soil $\mathrm{P}$ contents. It was found that $10.18 \mathrm{mg} \mathrm{P} \mathrm{kg}{ }^{-1}$ was recorded where SSP manually prepared was applied. While, as low as 7.97 mg $\mathrm{P} \mathrm{kg}^{-1}$ was observed in DAP, statistically at par with application of SSP + split N. the higher residual soil $\mathrm{P}$ content, irrespective of the $\mathrm{P}$ sources might be due to the rainfed condition of the field where less moisture content restricted the fertilizer dissolution in soil. The higher soil $\mathrm{P}$ content in case of SSP could be ascribed to lower soil fixation of $\mathrm{P}$ mainly due to acidic reaction (lower $\mathrm{pH}$ ). The effect of main plot (Biozote was also significant. Results show that biozote application enhanced the soil $\mathrm{P}$ content over non-inoculated treatment. The interaction between main-plot and sub-plot was also significant and the highest extractable $\mathrm{P}$ content was recorded in the treatment where $10.31 \mathrm{mg} \mathrm{kg}^{-1}$ self SSP was applied (Table 5).

Table 5: Effects of SSP, DAP and biozote on soil residual $P$ and plant $P$-uptake of wheat.

P-uptake of plants $\left(\mathrm{kg} \mathrm{ha}^{-1}\right)$

$\begin{array}{lllll}\text { Biozote } & \text { DAP } & \text { Self-SSP } & \text { Self-SSP+Split N } & \text { Mean } \\ \text { With } & 16.70 \mathrm{~d} & 17.65 \mathrm{~b} & 18.51 \mathrm{a} & 15.62 \mathrm{~A} \\ \text { Without } & 16.00 \mathrm{~d} & 17.03 \mathrm{c} & 17.58 \mathrm{bc} & 14.97 \mathrm{~B} \\ \text { Mean } & 10.50 \mathrm{C} & 17.34 \mathrm{~B} & 18.05 \mathrm{~A} & ----- \\ \text { Post-harvest soil P content }\left(\mathrm{mg} \mathrm{kg}^{-1}\right) & \\ \text { Biozote } & \text { DAP } & \text { Self-SSP } & \text { Self-SSP+Split N } & \text { Mean } \\ \text { With } & 8.34 \mathrm{c} & 10.31 \mathrm{a} & 9.00 \mathrm{~b} & 9.22 \mathrm{~A} \\ \text { Without } & 7.60 \mathrm{~d} & 10.05 \mathrm{a} & 7.77 \mathrm{~cd} & 8.47 \mathrm{~B} \\ \text { Mean } & 7.97 \mathrm{~B} & 10.18 \mathrm{~A} & 8.38 \mathrm{~B} & ------\end{array}$

SSP: Single superphosphate; DAP: Diammonium phosphate; Means followed by different letter(s) are statistically different $(p<0.05)$.

\section{Conclusions and Recommendations}

The study reconfirms that almost $50 \%$ available phosphorus can be solubilized from Hazara rock phosphate through the procedure adopted by the author, however, the solubilization can be increased by decreasing particle size of rock phosphate to be used for SSP preparation. The so prepared SSP gave yield advantage over DAP when applied at equal basis. Application of SSP with split application of urea superseded the yield of wheat under rainfed conditions.

\section{Acknowledgement}

Authors are grateful to the Research for Agricultural Development Program (RADP) of Pakistan Agricultural Research Council (PARC) for providing funds to undertake this study. 
Author's Contribution

Matiullah Khan: Conceived and executed all the experiments and drafted paper.

Shamimul Sibtain Shah: Farm operation services, land preparation, layout, inputs application and maintenance of experiments, input in write up.

Muhammad Atiqullah Khan: Farm operation services, land preparation, layout, inputs application and maintenance of experiments, input in write up.

Muhammad Sarwar: Overall supervision and guidance.

Shoaib Ahmad: Review collection, data analysis.

\section{References}

Alam, S.M.,A.Latif and Z.Iqbal.2002. Wheat yield and phosphorus use efficiency as influenced by method of phosphorus and Zinc application. Pak. J. Ind. Res. 45: 117-119.

Anonymous.2014.Agriculture statistics of Pakistan, Minist. Food Agric. Livestock, GoP, Islamabad. Aslam, M., T. Sultan, M. Saleemi and S. Ahmad. 2011. Role of plant growth promoting rhizobacteria (PGPR) and phosphate solublizing bacteria (PSB) in increasing wheat production in Pakistan. Proc. Prospects Challenges Sustainable Agric. July 11-16. Rawlakot: 425-425.

Aujla, K.M.,T.Mahmood and Akmal.2010. Wheat management practices and factors of yield decline in the Punjab province of Pakistan. Pak. J. Agric. Res. 23: 17-24.

Brady, N. 1990. The Nature and Properties of Soils. 8th edition. Macmillan publishers Co., Inc. New York.

Das, K.D., 2005. Introductory Soil Science. $4^{\text {th }}$ edition, Kalyani Publishers, New Delhi, India.

Fertilizer Manual. 1979. United Nations Industrial Development Organization (UNIDO) Vienna, Austria. Int. Fert. Dev. Centre (IFDC) Muscle Shoals, Alabama, USA.

Gardner, W.H. 1986. Methods of soil analysis Part 1. Phys. Minerol. Methods. Am. Soc. Agron. Madison, Wisconsim. 9: 493-541.

Goenadi, D.H. and S. Sugiarto. 2000. Bioactivation of poorly soluble phosphate rocks with a phosphorus solubilizing fungus. Soil Sci. Soc. Am. J. 64: 927-932.

Gomez, K.A. and A.A. Gomez. 1984. Statistical Procedures for Agricultural Research, $2^{\text {nd }}$ edition. John Wiley and Sons, New York, USA.

Huang, Q.N. 1998. Properties of phosphorus adsorption and desorption in red soil under a stand of Chinese fir in Fijian Nanjing. J. For. Universal. 22(2): 39-44.

Jackson,M.L.1973. Soil chemical analysis.PrenticeHall Inc. Englewood cliffs, New Jersey.

Javed, S., S. Waheed, N. Siddique, M. Tufail, M.M. Chaudhry and N. Irfan. 2008. Radio analytical and Nucl. Chem. 278: 17-24. https://doi. org/10.1007/s10967-007-7205-0

Kepert, D.G., A.D. Robson and A.M. Posner. 1979. The effect of organic root products on the availability of $\mathrm{P}$ to plants. In: The Soil-root Interface: (L. Harley and R. Scott. Russell Eds.) Acad. Press London. 115-124. https://doi. org/10.1016/B978-0-12-325550-1.50015-X

Khan, M., S. Ahmad, M. Sharif, M. Billah and M. Aslam. 2012. Formulation of single super phosphate fertilizer from rock phosphate of Hazara, Pakistan. Soil Environ. 31(1): 96-99.

Khan, M.B., M.I. Lone, R. Ullah, S. Kaleem and M. Ahmad.2010. Effect of different phosphatic fertilizers on growth attributes of wheat (Triticum aestivum L.). J. Am. Sci. 6: (12): 6062.

Koehler, F.E., C.D.Moudre and B.L.Mcneal. 1984. Laboratory manual for soil fertility. Wash. State Univ. Pulman, USA.

Kumari, A., K.K. Kapoor, B.S. Kundu and R.K. Mehta. 2008. Identification of organic acids produced during rice straw decomposition and their role in rock phosphate solubilization. J. Plants and Soil Environ. 54: 72-77. https://doi. org/10.17221/2783-PSE

McClean,E.O.1982. Soil $\mathrm{pH}$ and lime requirement. Methods of soil analysis Part 2.2nd ed. Agron. 9: 199-208. Madison, WI.

Memon, K.S., H.K. Puno and R.L. Fox. 1991. Phosphate sorption approach for determining phosphorus requirement of wheat in calcareous soils. Fert. Res. 28: 67-72. https://doi. org/10.1007/BF01048857

Molla, M.A.Z. and A.A. Chwodhury. 1984. Microbial mineralization of organic phosphates in Soil. Plant Soil. 78: 393-399. https://doi. org/10.1007/BF02450372

Mushtaq, A. 2015. Comparative performance of wheat in response to different phosphatic fertilizers Intl. J. Res. Agric. For. (2) 6: 1-9

Nelson, D.W. and L.E. Sommer. 1982. Total 
carbon, organic carbon and organic matter. In A.L. Page., R.H. Miller. and D.R. Keeney (ed.). Method of soil analysis part 2. 2nd (ed.) Agron. 9: 574-577.

Nisar A. and M. Rashid, 2003. Fertilizers and their use in Pakistan. An extension guide. Nat. Fert. Dev. Centre, Islamabad, Pakistan.

Nisar, A. 1996. Annual fertilizer review. NFDC Publ. No. 11/96. Islamabad, 31.

Olsen, S.R. and L.E. Sommers. 1982. Phosphorus. In A. L. Page (ed.), Methods of soil analysis, Agron. No. 9, part 2: Chemical and microbiological properties, 2nd ed., Am. Soc. Madison Wisconsim. 403-430.

Rashid, A. 2005. Soil Science. 3rd edition. Nat. book Found., Islamabad, Pak.

Reddy, M.P. and S.S. Singh. 2003. Effect of different sources of phosphatic fertilizers on growth and yield of wheat (Triticum aestivum L.). Crop Res. 26(3): 386-389.

Ryan. J., G. Eslefan and A. Rashid. 2001. Soil and plant analysis laboratory manual. Second edition Ed. Int. Centre Agric. Res. Dry Areas Aleppo,
Syria Nat. Agric. Res. Centre Islamabad. 15: 71-76.

Sharif, M., M.S. Sarir and F. Rabi. 2000. Biological and chemical transformation of phosphorus in some important soil series of NWFP. Sarhad J. Agric. 16 (6): 587-592.

Sharma and K. Arun. 2005. Bio-fertilizers for sustainable agriculture. Agronbios. India: 19498.

Soltonpour, P.N., and A.P. Schawab. 1977. A new soil test for simultaneous extraction of macro and micronutrient on alkaline soils. Comm. Soil Sci. Plant Anal. 8: 195-207.

Tandon, D.W., Nelson and L.E. Sommers. 2005. Total carbon, organic carbon and organic matter. FDCO, New Delhi, India, In: Methods of soil analysis: Part 3- Chemical methods. J.M. Bigham (ed.). Am. Soc. Agron. Inc. Medison, Wisconson. 961-1010.

Tisdale, L.S., L.W. Nelson, D.J. Beaton and J.L. Haulin. 2002. Soil fertility and fertilizers. Macmillan Publ. Co. New York, Tor. Oxf. Singapore. p: 633. 